ing some pieces of mackerel. Thus this animal, which is very poor in respiratory blood pigments, shows normal habits of feeding, proving that its olfactory organs were in good physiological condition. Hence the pathological state of the blood of this hag-fish leads one to ask what is the limiting role which could be taken by hæmoglobin in the life of Myxine.

My thanks are due to Dr. Swedmark, director of the Kristinobergs Zoologiska Station, Fiskebäckskill, Sweden, for providing many living hag-fishes.

Laboratory of Zoophysiology,

B. RYBAK

$$
\text { University of Caen. }
$$

'De Graaf, A. R., J.Exp. Biol., 34, 173 (1957).

Ewer, D. W., Nature, 183, 271 (1959)

Gustafson, G. J., Ark. Zool., 28, A, No. 2 (1934).

\section{Interlaminate Figures of Sessile Barnacle Shells}

Alessandri ${ }^{1}$, Gruvel ${ }^{2}$ and Davadie-Suaudeau ${ }^{3}$, in their works on the cirripedes, have directed attention to figures or patterns in the shell plates of various species of sessile barnacles, and further work may prove these to be an important taxonomic characteristic for species identification; but this seems to have been somewhat neglected.

The usual method of identifying barnacles is often difficult due to the variability of the shell configurations and must frequently be followed by examination of the soft parts-a tedious undertaking. Even then, mistakes in naming have occurred, but work by Cornwall ${ }^{4-6}$ on many specimens has shown that the 'interlaminate' figures are specific and constant for recent and fossil barnacles.

The following method of revealing the figures is a modification of the procedure using plaster of Paris as described by Cornwall. Whole specimens or plate fragments are embedded in 'N.H.P.' mounting plastic (obtained from North Hill Plastics, Ltd., London). Rings of tubular rubber, polythene or cardboard are cut to fit the size of the specimen to be mounted. The rings are placed on a glass plate to which is applied a thin coating of 'Vaseline' and the specimen carefully placed, basis downwards, within the ring. A small amount of the plastic powder ('N.H.P. $2031 / 19^{\prime}$ ) is spread over and around the specimen and thoroughly wetted with the plastic fluid ('N.H.P. 1844'). When the first application of liquid has been absorbed a fresh portion of powder, followed by more liquid, is added. This procedure is repeated until all, or as much as is thought necessary, of the specimen is covered. Leave to dry and harden (30-60 min.). When complete specimens are to be mounted it is advisable to fill the shell cavity with plastic by turn. ing the mounting ring over and repeating the above process. When ready, the embedded specimen is extruded from the ring or, if this proves impossible, it is cut away and is ready for grinding and polishing.

It is necessary, in order to show the figures to their best advantage, to ensure that the surface to be examined is as flat and even as possible. A coarse grinding is done on a glass plate with wet 320 silicon carbide powder followed by a similar grinding on a second plate with 700 powder. Grinding should be done until the parietal canals are visible. This can be controlled by examining the ground surface at intervals with a hand lens. After grinding, the surface is given a rinse with water to remove any adhering carbide particles and then dried by pressing on to a filter paper. Polishing is done with diamond paste on a chamois leather followed by a final buffing on a dry chamois leather.

The figures are best seen at a magnification of between 20 and 50 with the light from the top and slightly to the side of the mounted specimen. A few drops of water or benzyl alcohol ${ }^{5,6}$ run on to the prepared surface between a cover-slip will often help reveal figures which tend to 'disappear' when the mount is dry. Orienting the specimen to the light is also a help in showing up details of the figures. One of the great advantages of the method outlined above is that the mounted specimen can be dissolved out of the plastic mount by steeping in chloroform, when it can be retrieved intact except for the small portion which has been ground away.

Certain species such as Balanus balanoides and Elminius modestus have not shown any figures in preparations from the basis. This may be due to the fact that these species do not have any parietal canals (Crisp, D. J., personal communication). It may be that such species will show figures if preparations are made from the ala of the wall plates ${ }^{6}$.

An atlas of the interlaminate figures from identified barnacle specimens would be of great value for the further identification of species and would help in furthering this work.

43 Holly Terrace, Hensingham,

R. READ

Whitehaven, Cumberland.

Dec. 12.

${ }^{1}$ Alessandri, Guido de, Boll. Soc. Geol. Italiana, 13, 3, 234 (1895). "Gruvel, A., "Monographie des Cirrhipedes ou Theocostraces" (1905). ${ }^{3}$ Davadie-Suaudeau, (Madam) Claude, Bull. du Service de la Carte Géologique de l'Algérie, Ser. 1, Paléontologie, Yo. $14(1952)$. ${ }^{4}$ Cornwall, I. E., J. Paleontol., 30, 3 (1956).

${ }^{5}$ Cornwall, I. E., Canad. J. Zool., 36, 79 (1958).

'Cornwall, I. E., Canad. J. Zool., 37, 401 (1959).

\section{Seed Incompatibility in Primula}

When diploid and autotetraploid plants of Primula veris are artificially crossed reciprocally, fertilization occurs and seed is set, but the seed is bad and germination is nil; the same is true for Primula vulgaris and $P$. elatior. Similar seed incompatibility (as it may be called) between diploids and their colchicine-induced autotetraploids has been reported in several other genera of flowering plants, for example, Gossypium ${ }^{1}$ and Galeopsis ${ }^{2}$; it is associated with post-fertilization breakdown of the seed tissues, in particular the endosperm. On the other hand, in some genera, for example, Beta ${ }^{3}$, the crosses are easily made and viable triploids can be produced in large numbers. The reasons for these different types of behaviour are not known, but they are probably connected with differences in the nature and mode of functioning of the tissues concerned in the nutrition and protection of the embryo; it is worth noting that these tissues (the endosperm and the maternal nucellus and endothelium) generally differ in genetic constitution both from the embryo and also from one another.

The seeds produced in the reciprocal diploidtetraploid crosses in Primula are of two types, according to the direction of the cross; similar contrasting seed types are found in a number of diploid interspecific crosses in this group 4 . This is shown in Table 1 , where the $P$. elatior $-P$. veris cross is used as an illustration.

In these crosses, type $A$ seed is very small, with abnormally thick integuments, a small amount of 